REPORTS OF MORPHOLOGY
Official Journal of the Scientific Society of Anatomists,
Histologists, Embryologists and Topographic Anatomists
of Ukraine
journal homepage: https://morphology-journal.com

\title{
Histological features of the mitral valve in norm and opioid exposure in experiment
}

\author{
Mateshuk-Vatseba L.R. ${ }^{1}$, Symivska R.R. ${ }^{1}$, Belik N.V. ${ }^{2}$, Piliponova V.V. ${ }^{2}$
}

${ }^{1}$ Lviv National Medical University named after Danylo Halytskyi, Lviv, Ukraine

${ }^{2}$ National Pirogov Memorial Medical University, Vinnytsya, Ukraine

\begin{tabular}{|c|c|}
\hline $\begin{array}{l}\text { CORRESPONDING AUTHOR } \\
\text { e-mail: Ivatseba@gmail.com } \\
\text { Mateshuk-Vatseba L.R. }\end{array}$ & $\begin{array}{l}\text { To date, pathology of the cardiovascular system is the most common, tends to increase, } \\
\text { most often leads to disability and mortality of the population at a young working age and } \\
\text { is an important medical and social problem. The purpose of the study was to establish } \\
\text { the features of micro organization of the mitral valve in white rat in norm and after opioid } \\
\text { action. The study material is presented by histological samples of a mitral valve of the } \\
\text { white rat. The study was performed on } 30 \text { adult white reproductive age rats weighing } \\
160-220 \mathrm{~g} \text {. The experimental animals were injected intramuscularly } 1 \text { time per day for } \\
\text { the same period of } 42 \text { days ( } 6 \text { weeks) with the opioid drug analgesic "Nalbuphine". } \\
\text { Using histological methods, } 30 \text { mitral valves of white rat were examined. Microscopy of } \\
\text { histological preparations of the valves of the heart was performed sequentially, assessing } \\
\text { the morphological changes in the norm and under the action of the opioid after } 6 \text { weeks } \\
\text { of the experiment. Emphasis was placed on the presence or absence of endothelial } \\
\text { layer, as well as the condition of endothelial cells in normal and at the action of the } \\
\text { damaging factor, determining the signs of their dystrophy, desquamation and proliferation. } \\
\text { It is established that the normal mitral valve is represented by endocardial folds. The } \\
\text { rat endocardium consists of three layers: endothelial (endothelial cells rich layer, } \\
\text { attached to the basement membrane), subendothelial (connective tissue rich in } \\
\text { fibroblasts) and a muscular-elastic layer (represented by smooth myocytes, plaited } \\
\text { collagen fibers). After } 6 \text { weeks of administration of Nalbuphine, the mitral valve is in a } \\
\text { stage of decompensation, when the outer and inner endothelial layers are destroyed, } \\
\text { the endothelial cells are deformed, the subendothelial layer is represented by single } \\
\text { bundles of different directions. In the musculo-elastic layer, contact between smooth } \\
\text { myocytes and fragmented and thinned, collagen and elastic fibers is lost. This study } \\
\text { allows us to conclude on the destructive effect of opioid agents on the valvular apparatus } \\
\text { of the heart. } \\
\text { Keywords: mitral valve, histology, opioid, white rat, norm. }\end{array}$ \\
\hline
\end{tabular}

\section{Introduction}

This article presents and analyzes data from studies conducted on white rats of reproductive age. Despite the fact that the average life expectancy in modern society is increasing significantly due to the development of experimental and clinical medicine, cardiovascular diseases have become the leading cause of death in the world over the last 10 years, accounting for $30 \%$ of all cases and $45 \%$ of all non-communicable causes of death. [1-5, 8]. According to $\mathrm{WHO}$, about $90 \%$ of all diseases are associated with pain, and patients with chronic pain are five times more likely to seek medical treatment, compared with the general population [21]. One of the issues remains the use of opioids in clinical practice, in particular for the treatment of postoperative and chronic pain [14, 22, 24, 25]. According to epidemiological studies, the prevalence of chronic pain syndromes is at least $40 \%$ of the adult population and these figures tend to increase steadily $[7$, $10,20,21]$. A systematic analysis of original studies of the prevalence of symptoms in patients at the terminal stage of the disease, found that $35-96 \%$ of cancer patients, 63$80 \%$ of patients with AIDS, $41-77 \%$ of patients with cardiovascular disease, $34-77 \%$ of patients with chronic obstructive pulmonary diseases and $45-70 \%$ with kidney diseases - have a pronounced pain syndrome [19]. There is an increasing trend in the world of opioid use, which contributes to the improvement of somatic, visceral and 
neuropathic pain. Not infrequently, the opioid arsenal and physicians' knowledge is limited by the use of morphine, which for a long time has been the "gold standard", the most common drug in its group. According to research, there are significant differences in the amount of morphine consumed by high-income countries compared to middleand low-income countries [11]. For example, the International Narcotics Control Committee (INCC) reports that about $92 \%$ of the worldwide use of morphine is consumed in countries with only $17 \%$ of the world's population (US, Canada, Western Europe, Australia and New Zealand). About $75 \%$ of the world's population in more than 100 countries do not have or have insufficient access to proper treatment for severe pain [12]. However, the biggest problem with using morphine is the lack of a "marginal effect" and linear dose-response. That is why, at the moment, it is important to find alternative methods of analgesia and to study their effects on the human body.

The purpose of the study is to determine the features of the micro organization of mitral valve white rat in norm and after opioid.

\section{Materials and methods}

The study material is represented by mitral valve histological samples of the white rat. The study was performed on 30 adult white reproductive rats weighing 160-220 g. The experimental animals were divided into 3 series of 10 animals. In the first series the features of angioarchitectonics of the valves of white rats were normal, in the second series the dynamics of qualitative and quantitative structural changes of the valves against the background of prolonged exposure to opioids in the experiment after 6 weeks, the third series served as a control. Experimental animals were injected intramuscularly 1 time per day for the same period of time for 42 days ( 6 weeks) by the opioid drug analgesic "Nalbuphine". Each week, the dose of the drug for injection was increased in sequence: $1 \mathrm{st}$ week - $8 \mathrm{mg} / \mathrm{kg}$, 2nd week - $15 \mathrm{mg} / \mathrm{kg}$, 3rd week - $20 \mathrm{mg} / \mathrm{kg}$, 4th week - $25 \mathrm{mg} / \mathrm{kg}$, 5th week - $30 \mathrm{mg} / \mathrm{kg}$, 6 th week - $35 \mathrm{mg} / \mathrm{kg}$ [16]. Animals were withdrawn from the experiment 6 weeks after opioid administration. The sampling of rat heart valves was performed after euthanasia by intraperitoneal anesthesia overdose using sodium thiopental (calculated at $25 \mathrm{mg} / \mathrm{kg}$ body weight).

All experimental animals were kept in the vivarium of Lviv National Medical University named after Danylo Halytskyi. The studies were conducted in accordance with the provisions of the European Convention for the Protection of Vertebrate Animals Used for Experimental and Other Scientific Purposes (Strasbourg, 1986), Council of Europe Directives 86/609/EEC (1986), Law of Ukraine No.3447-IV, on the "Protection of Animals from Cruelty behavior", the general ethical principles of animal experimentation, approved by the First National Congress of Ukraine on Bioethics (2001).
Images from histological specimens of the mitral valve on a computer monitor were taken from a MICROmed SEO SSCAN microscope and using a Vision CCD Camera. The studies were performed at certain times of the experiment in preparations stained with hematoxylin-eosin.

\section{Results}

Mitral valve consists of two leaflets. Histologically, the left atrioventricular valve is represented by endocardial folds (Fig. 1). The endocardium of the mitral valve consists of 3 layers. Internal and external - endothelial - in the form of a layer of flat polygonal shape, elongated cells with irregular wavy edges. On the inner surface (facing the ventricle cavity), the endothelial cells contain many microvilli. On the outer surface of the valves (facing the atrial cavity), the endothelial cells are located much further apart from the layer of the inner endothelium. The subendothelial layer is represented by a fibroblast-rich connective tissue. As a part of this connective tissue base there are superficial fibrous and deep spongy layers. The superficial fibrous layer is a dense connective tissue with a small number of cells, thick bundles of collagen fibers oriented in different directions, which provides durability under various factors. Collagen fiber bundles are delimited by thin layers of the basic substance, fibrocyte bodies, and single elastic fibers. The thin collagen fibers of the endocardium gradually move into the fibrous plate of the valve leaf, and at the place of attachment of the mitral and tricuspid valves into fibrous rings. The deep spongy layer is a loose connective tissue rich in cells. The musculoelastic layer is represented by smooth myocytes, braided collagen fibers with fibroblasts and large number of elastic fibers.

At the base of the valves, the endocardium is separated from the myocardium by a connective tissue base containing thick elastic, collagen and reticular fibers. Blood vessels and nerves are placed between them. The atrial side of the valves has a smooth surface. The endothelial layer is more pronounced and denser than the ventricular side. The

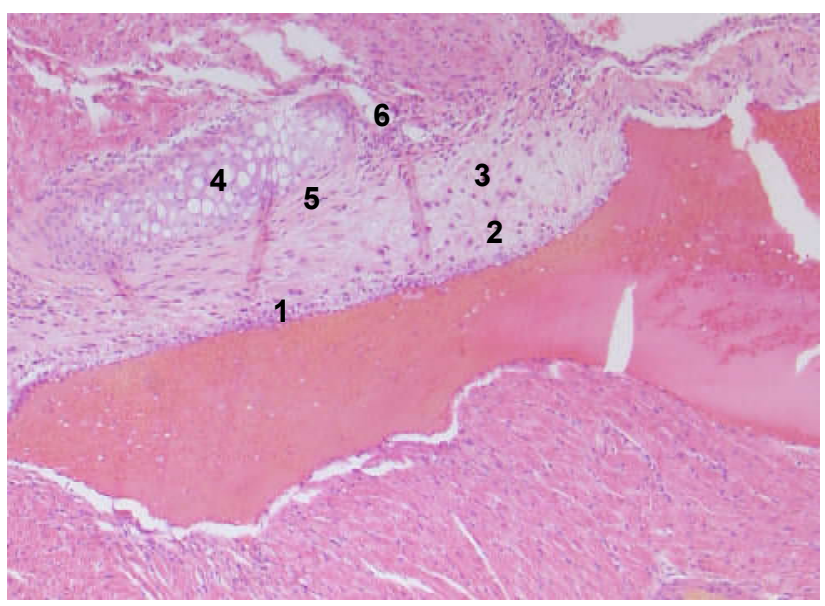

Fig. 1. White rat mitral valve base endocardium. 1 - endothelial cells on the basement membrane; 2 - tufts of collagen fibers; 3 fibroblast bodies; 4 - fibrous ring; 5 - nuclei of smooth muscle cells; 6 - blood capillaries. Hematoxylin-eosin staining. x200. 


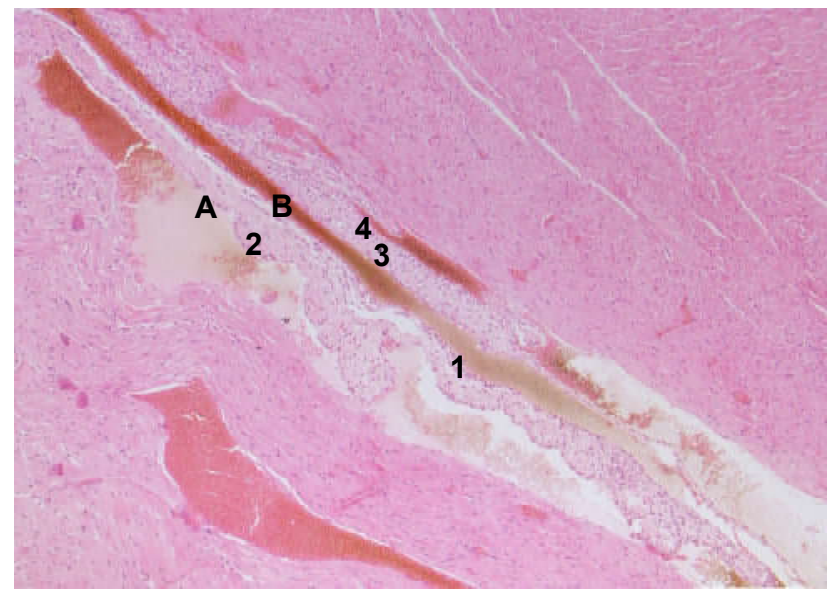

Fig. 2. A - atrial side of leaflets of valve; B - ventricle side leaflets of valve; 1 - layer of endothelial cells on the basement membrane; 2 - tufts of collagen fibers; 3 - elastic fibers; 4 - nuclei of connective tissue cells. Hematoxylin-eosin staining. $x 200$.

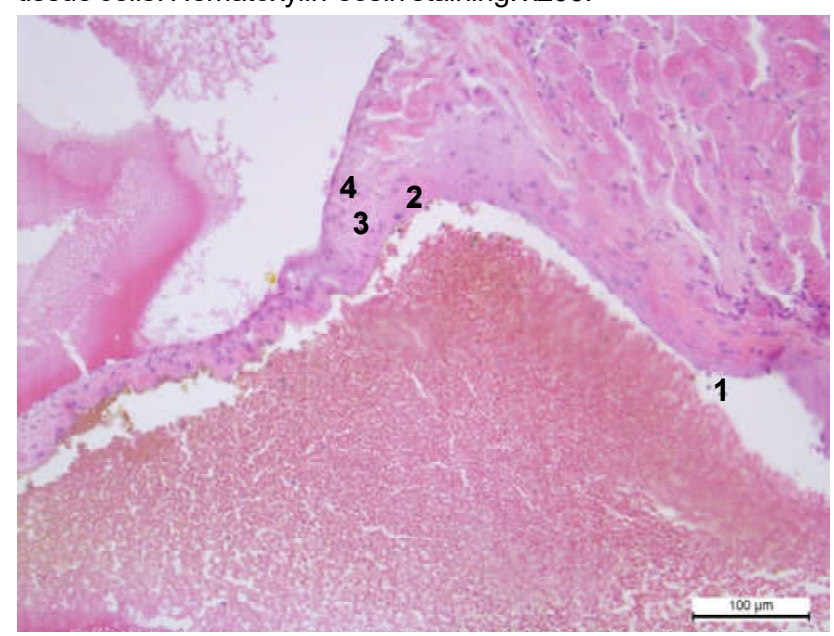

Fig. 3. White rat mitral valve base endocardium, week 6 of the experiment. 1 - detachment of endothelial cells in the lumen of the right ventricle; 2 - single endothelial cells on a thinned basal membrane; 3 - fragmented collagen fibers; 4 - single bodies of fibroblasts. Hematoxylin-eosin staining. x100.

ventricular side has an uneven surface because of the outgrowths from which the tendon filaments begin. In this area, only a few elastic fibers are located below the endothelium (Fig. 2).

After 6 weeks of nalbuphine administration, deep destructive changes are observed: in the inner layer, the endothelial cells are not attached to the basement membrane, irregularly shaped and without processes. The single endothelial cells remaining on the basement membrane lost their polygonal shape and connections. In the outer layer, single, irregularly shaped endothelial cells attach to a thin basal membrane and form valve structures with each other or lose contact with it. In the subendothelial layer there is a small amount of multidirectional collagen fibers, a large amount of basic substance and fibrocytes. Fibroblasts are presented in small numbers. Collagen fiber bundles have become thinner and more fragmented. In the musculoelastic layer, contact between smooth myocytes, thin bundles of collagen and elastic fibers was lost. The gaps between the structural components are taken up by the basic substance. A small amount of collagen fibers and fibroblasts are located between the main substance (Fig. 3).

\section{Discussion}

Depending on the extracardiac and intracardiac factors, a number of studies by both morphologists-experimenters and clinicians have been devoted to the study of the adaptive capacity of the injured heart [23]. It should also be noted that in recent years, morphometric methods have been widely used in biomedical research, which allow to study qualitative and quantitative patterns of physiological and pathological processes, to adequately objectify and logically interpret them $[6,13]$. However, there are almost no studies that would comprehensively study heart valves at all levels of structural organization and under the conditions of action on the body of opioids. The relevance of this work is that the microscopy of histological preparations of the heart valves was performed sequentially, evaluating the morphological changes in normal and opioid exposure after 6 weeks of the experiment. Emphasis was placed on the presence or absence of endothelial layer, as well as the condition of endothelial cells in normal and at the action of the damaging factor, determining the signs of their dystrophy, desquamation and proliferation. There is sufficient information in the literature regarding the effects of opioid agents on the sense organs [17], the skin [15], and etc. There are experimental works describing the decompensation of the hemomicrocirculatory bed with prolonged exposure to opioids, when the capillary component is destroyed, arterioles are twisted and deformed, venules are enlarged [18]. Fundamental is the work to formulate a list of macro- and microscopic changes in heart valve structures that are characteristic of acquired heart defects of inflammatory and non-inflammatory genesis, and morphological groups that are typical only of rheumatic heart disease, infectious endocarditis, and acquired heart defects of non-inflammatory nature [9]. The novelty of this study is that there are no data on the effect of opioid agents on cardiac function, namely the morphological changes of the valvular apparatus under the influence of opioids, some studies are observational and the findings are insufficiently substantiated.

The prospect of further research in this direction is related to the further study of the histological organization of the valvular apparatus of the heart under the action of opioid agents.

\section{Conclusions}

1. In the norm, the mitral valve rat is represented by the folds of the endocardium, consisting of three layers: endothelial, subendothelial and musculoelastic.

2. After six weeks of administration of nalbuphine, mitral valve is in the stage of decompensation - the outer and 
inner endothelial layers are destroyed, the endothelial cells are deformed, the subendothelial layer is represented by single bundles of multidirectional and destroyed collagen

\section{References}

[1] Abdulkareem, N., Smelt, J., \& Jahangiri, M. (2013). Bicuspid aortic valve aortopathy: genetics, pathophysiology and medical therapy. Interactive Cardiovascular and Thoracic Surgery, 17(3), 554-559. doi: 10.1093/icvts/ivt196

[2] Akyüz, A. R., \& Kul, S. (2015). Bicuspid aortic valve and extremely elongated chordae tendineae protruding into the left ventricular outflow tract. Anadulu Kardiyoloji Dergisi: $A K D$, 15(5), E14. doi: 10.5152/akd.2015.6090

[3] Alegret, J. M., Martinez-Micaelo, N., Aragonés, G., \& BeltránDebón, R. (2016). Circulating endothelial microparticles are elevated in bicuspid aortic valve disease and related to aortic dilation. International Journal of Cardiology, 217, 35-41. doi: 10.1016/j.ijcard.2016.04.184

[4] Alegret, J. M., Masana, L., Martinez-Micaelo, N., Heras, M., \& Beltrán-Debón, R. (2015). LDL cholesterol and apolipoprotein $B$ are associated with ascending aorta dilatation in bicuspid aortic valve patients. QJM: An International Journal of Medicine, 108(10), 795-801. doi: 10.1093/qjmed/hcv032

[5] Björck, H. M., Du, L., Pulignani, S., Paloschi, V., Lundströmer, K., Kostina, A. S., ... \& Teixidó-Tura, G. (2018). Altered DNA methylation indicates an oscillatory flow mediated epithelialto-mesenchymal transition signature in ascending aorta of patients with bicuspid aortic valve. Scientific Reports, 8(1), 1-15. doi: 10.1038/s41598-018-20642-4

[6] Cameli, M., Lisi, M., Righini, F. M., \& Mondillo, S. (2012). Novel echocardiographic techniques to assess left atrial size, anatomy and function. Cardiovascular Ultrasound, 10(1), 1014. doi: $10.1186 / 1476-7120-10-4$

[7] Emonet, S., Wuillemin, T., Harbarth, S., Wassilew, N., Cikirikcioglu, M., Schrenzel, J. ... Van Delden, C. (2015). Relapse of Tropheryma whipplei endocarditis treated by trimethoprim/ sulfamethoxazole, cured by hydroxychloroquine plus doxycycline. International Journal of Infectious Diseases, 30, 17-19. doi: 10.1016/j.ijid.2014.11.003

[8] Endo, M., Nabuchi, A., Okuyama, H., Muto, Y., Hiranuma, S., Miyazaki, T. ... Hashimoto, O. (2015). Differing relationship between hypercholesterolemia and a bicuspid aortic valve according to the presence of aortic valve stenosis or aortic valve regurgitation. General Thoracic and Cardiovascular Surgery, 63(9), 502-506. doi: 10.1007/s11748-015-0561-8

[9] Fedoniuk, L. Ya. (2008). Structural organization of changes of the valve Apparatus at Acquired Heart Defects (Doctoral dissertation). https://otherreferats.allbest.ru/medicine/ 00603084_0.html

[10] Gear, R. W., Gordon, N. C., Hossaini-Zadeh, M., Lee, J. S., Miaskowski, C., Paul, S. M., \& Levine, J. D. (2008). A subanalgesic dose of morphine eliminates nalbuphine antianalgesia in postoperative pain. The Journal of Pain, 9(4), 337-341. doi: 10.1016/j.jpain.2007.11.011

[11] Gilson, A. M., Maurer, M. A., Ryan, K. M., Rathouz, P. J., \& Cleary, J. F. (2013). Using a morphine equivalence metric to quantify opioid consumption: examining the capacity to provide effective treatment of debilitating pain at the global, regional, and country levels. Journal of Pain and Symptom Management, 45(4), 681-700. doi: 10.1016/ j.jpainsymman.2012.03.011

[12] International Narcotics Control Board. (2011). Report of the International Narcotics Control Board on the availability of fibers. In the musculoelastic layer, contact between smooth myocytes and fragmented and thinned collagen and elastic fibers is lost.

internationally controlled drugs: ensuring adequate access for medical and scientific purposes. UN.

[13] Kovalenko, V. M., Nesukai, O. G., Polenova, N. S. (2012). Three-dimensional echocardiography: a technique and a role in the study of the structure and function of the heart valves. Heart Failure, (3), 7-13.

[14] Kshirsagar, S., Gear, R., Levine, J., \& Verotta, D. (2008). A mechanistic model for the sex-specific response to nalbuphine and naloxone in postoperative pain. Journal of Pharmacokinetics and Pharmacodynamics, 35(1), 69-83. doi: 10.1007/s10928-007-9076-y

[15] Mateshuk-Vatseba, L. R., Bekesevych, A. M., Diskovskyi, I. S., Zinko, A. V., Pidvalna, U. E., \& Popyk, P. M. (2015). Patterns of structural changes in the links of the hemomicrocirculatory bed of organs under the conditions of opioid exposure in the experiment. Topical Issues of Medical Science and Practice, 82, 16(1), 328-335.

[16] Onysko, P. M., Paltov, E. V., \& Fik, V. B. (2012). Method for modeling physical opioid dependence in rats. Patent, Ukraine №76564U

[17] Pidvalna, U. E. (2014). Structural organization of organs and systems under the influence of opioids. Experimental and clinical physiology and biochemistry, (1), 65, 71-78.

[18] Savchenko, S. V. (2012). Actual issues of expert assessment of heart morphology. Bulletin of Forensic Medicine, 1(3), 5-8.

[19] Solano, J. P., Gomes, B., \& Higginson, I. J. (2006). Acomparison of symptom prevalence in far advanced cancer, AIDS, heart disease, chronic obstructive pulmonary disease and renal disease. Journal of Pain and Symptom Management, 31(1), 58-69. doi: 10.1016/j.jpainsymman.2005.06.007

[20] Stevens, S. M., \& Doty, J. R. (2017). New evidence on old drugs; warfarin versus aspirin after bioprosthetic aortic valve placement. Thrombosis Research, 150, 102. doi: 10.1016/ j.thromres.2016.12.015

[21] Toyama, S., Tagaito, Y., \& Shimoyama, M. (2016). Patientcontrolled epidural analgesia for labour in a patient after Ross procedure for congenital bicuspid aortic valve. Journal of Obstetrics and Gynaecology, 36(8), 1010-1011. doi: 10.1080/ 01443615.2016.1234441

[22] Voronkov, M., Ocheret, D., Bondarenko, S., \& Ivanov, Y. (2008). Administration of nalbuphine to heroin addicts. Feasibility and short-term effects. Heroin Addiction and Related Clinical Problems, 10(1), 19-24.

[23] Yasinovskyi, O. B. (2015). Remodeling of chambers and vascular bed during intoxication with cadmium and aluminum salts ( $\mathrm{PhD}$ thesis). http://www.irbis-nbuv.gov.ua

[24] Yeh, Y. C., Lin, T. F., Chang, H. C., Chan, W. S., Wang, Y. P., Lin, C. J., \& Sun, W. Z. (2009). Combination of low-dose nalbuphine and morphine in patient-controlled analgesia decreases incidence of opioid-related side effects. Journal of the Formosan Medical Association, 108(7), 548-553. doi: 10.1016/S0929-6646(09)60372-7

[25] Yeh, Y. C., Lin, T. F., Lin, F. S., Wang, Y. P., Lin, C. J., \& Sun, W. Z. (2008). Combination of opioid agonist and agonist-antagonist: patient-controlled analgesia requirement and adverse events among different-ratio morphine and Nalbuphine admixtures for postoperative pain. British Journal of Anaesthesia, 101(4), 542-548. doi: 10.1093/bja/aen213 


\section{ГІСТОЛОГІЧНІ ОСОБЛИВОСТІ ДВОСТУЛКОВОГО КЛАПАНА СЕРЦЯ В НОРМІ ТА ПРИ ДІЇ ОПІОЇДУ В ЕКСПЕРИМЕНТІ Матешук-Вацеба Л.Р., Симівська Р.Р., Белік Н.В., Піліпонова В.В.}

На сьогоднішній день патологія серцево-судинної системи є найбільш розповсюдженою, має тенденцію до збільшення, найчастіше призводить до інвалідності та смертності населення у молодому працездатному віці та є важливою медичною і соціальною проблемою. Мета дослідження - встановлення особливостей мікроорганізації двостулкового клапана серия білого щура в нормі та за умови дії опіоїду. Матеріал дослідження представлений гістопрепаратами двостулкового клапана серця білого щура. Дослідження виконано на 30 статевозрілих білих щурах репродуктивного віку масою 160-220 2. Експериментальним тваринам вводили внутрішньом'язово 1 раз на добу в однаковий проміжок часу протягом 42 днів (6 тижнів) опіоїдний наркотичний анальгетик "Налбуфін". За допомогою гістологічних методів були вивчені 30 двостулкових клапанів білого щура. Мікроскопію гістологічних препаратів клапанів серия проводили послідовно, оцінюючи їх морфологію в нормі та при дії опіоїду через 6 тижнів експерименту. Акцентували увагу на присутність чи відсутність ендотеліального шару, а також стан ендотеліоцитів у нормі та при дії пошкоджуючого фрактора, визначаючи ознаки їх дистрофрії, десквамації та проліфрерації. Встановлено, що, зазвичай, двостулковий клапан серця щура представлений складками ендокарда. Ендокард щура складається з трьох шарів: ендотеліального (багатого ендотеліоцитами прикріпленими до базальної мембрани), підендотеліального (сполучна тканина, котра багата на фрібробласти) та м'язово-еластичного шару (представлений гладкими міоцитами, обплетеними пучками колагенових та еластичних волокон). Двостулковий клапан серия після 6тижневого введення налбуфріну знаходиться на стадії декомпенсації, коли зовнішній та внутрішній ендотеліальні шари зруйновані, ендотеліоцити деформовані, підендотеліальний шар представлений поодинокими пучками різнонапрямлених та знищених колагенових волокон, невеликою кількістю клітин, які розміщені між основною речовиною. У м'язово-еластичному шарі втрачається контакт між гладкими міоцитами та фррагментованими і стоншеними колагеновими й еластичними волокнами. Дане дослідження дозволяє зробити висновки щодо деструктивного впливу опіоїдних складових на клапанний апарат серия.

Ключові слова: двостулковий клапан, гістологія, опіоїд, білий щур, норма.

\section{ГИСТОЛОГИЧЕСКИЕ ОСОБЕННОСТИ ДВУСТВОРЧАТОГО КЛАПАНА СЕРДЦА В НОРМЕ И ПРИ ВОЗДЕЙСТВИИ ОПИОИДА В ЭКСПЕРИМЕНТЕ}

Матешук-Вацеба Л.Р., Симивська Р.Р., Белик Н.В., Пилипонова В.В.

На сегодняшний день патология сердечно-сосудистой системы является наиболее распространенной, имеет тенденцию к росту, зачастую приводит к инвалидности и смертности населения в молодом трудоспособном возрасте и является важной медицинской и социальной проблемой. Цель исследования - установление особенностей микроорганизации двустворчатого клапана сердца белой крысы в норме и при воздействии опиоида. Материал исследования представлен гистопрепаратами двустворчатого клапана сердиа белой крысы. Исследование выполнено на 30 половозрелых белых крысах репродуктивного возраста массой 160-220 г. Экспериментальным животным вводили внутримышечно 1 раз в сутки в одинаковый промежуток времени в течение 42 дней (6 недель) опиоидный наркотический анальгетик "Налбуфрин". С помощью гистологических методов были изучены 30 двустворчатых клапанов белой крысы. Микроскопию гистологических препаратов клапанов сердца проводили последовательно, оценивая их морфологию в норме и при воздействии опиоида через 6 недель эксперимента. Акцентировали внимание на присутствие или отсутствие эндотелиального слоя, а также состояние эндотелиоцитов в норме и при воздействии повреждающего фрактора, определяя признаки их дистрофии, десквамации и пролиферации. Установлено, что в норме двустворчатый клапан сердца крысы представлен складками эндокарда. Эндокард крысы состоит из трех слоев: эндотелиального (богатого эндотелиоцитами, прикрепленными к базальной мембране), подэндотелиального (соединительная ткань, которая богата фибробластами), и мышечноэластического слоя (представлен гладкими миоцитами, оплетенными пучками коллагеновых и эластических волокон). Двустворчатый клапан сердца после 6-недельного введения налбуфина находится на стадии декомпенсации, когда внешний и внутренний эндотелиальные слои разрушены, эндотелиоциты деформированы, подэндотелиальный слой представлен единичными пучками разнонаправленных и уничтоженных коллагеновых волокон, небольшим количеством клеток, расположенных между основным веществом. В мышечно-эластичном слое теряется контакт между гладкими миоцитами и фррагментированными и истонченными коллагеновыми и эластическими волокнами. Данное исследование позволяет сделать выводы относительно деструктивного влияния опиоидных составляющих на клапанный аппарат сердца. Ключевые слова: двустворчатый клапан, гистология, опиоид, белая крыса, норма. 